\title{
Improving strategic diagnoses
}

To foster the mutation of tourism destinations into sustainable development ventures

Corinne Van der Yeught

\section{(2) OpenEdition \\ 1 Journals}

Electronic version

URL: http://journals.openedition.org/tourisme/321

DOI: $10.4000 /$ tourisme.321

ISSN: 2492-7503

\section{Publisher}

Éditions touristiques européennes

\section{Printed version}

Date of publication: 1 June 2010

Number of pages: $59-75$

ISSN: $2109-5671$

\section{Electronic reference}

Corinne Van der Yeught, «Improving strategic diagnoses », Mondes du Tourisme [Online], 1 | 2010,

Online since 30 September 2015, connection on 01 May 2019. URL : http://journals.openedition.org/ tourisme/321 ; DOl : 10.4000/tourisme.321

\section{cc)}

Mondes du tourisme est mis à disposition selon les termes de la licence Creative Commons Attribution

- Pas d'Utilisation Commerciale - Pas de Modification 4.0 International. 


\section{Improving strategic diagnoses}

\section{to foster the mutation of tourism destinations into sustainable development ventures}

\section{CORINNE VAN DER Yeught}

Abstract. This paper proposes a strategic diagnosis framework, derived from the resource-based view, in order to help tourism destinations mutate into sustainable development ventures. A resource-based approach points towards defining a tourism destination as a set of productive and human, tangible and intangible resources, which can generate sustained competitive advantages. In that respect, the first stage of a strategic diagnosis should be to identify and to classify a destination's strategic resources. Thanks to the literature and to the observation of three European destinations located on the Mediterranean Sea, three criteria for a typology of resources are proposed: their sustainability dimension, their attractiveness for tourists and their inherited or created nature. The research produces a resource-based strategic diagnosis method that will help destination leaders identify the strategic assets and the path dependency of the destinations they manage. They can then define strategic options, improving both competitiveness and sustainability.
Maître de conférences en sciences de gestion, laboratoire Ermmes-IAE de Toulon, université du Sud Toulon-Var

[corinne.vanderyeught@free.fr]

Résumé. L'objet de cet article est de proposer une méthodologie de diagnostic stratégique, fondée sur la resource-based view (RBV), permettant d'accompagner la mutation des destinations touristiques engagées dans des stratégies de développement durable. Selon une approche resource-based, une destination touristique peut être définie comme un ensemble de ressources productives, physiques et humaines, tangibles et intangibles, susceptibles d'engendrer des avantages concurrentiels "soutenables". Dans cet article, trois critères conduisant à une typologie des ressources stratégiques "durables" sont proposés à partir d'une revue de la littérature et de l'étude longitudinale de trois destinations européennes du pourtour méditerranéen : la dimension de la durabilité concernée ; l'attractivité touristique de la ressource ; son caractère hérité ou construit. La méthodologie de diagnostic stratégique élaborée permet d'identifier les actifs stratégiques et la "dépendance de sentier" des destinations étudiées. Elle aide ainsi les responsables de ces destinations à définir des options stratégiques dans une perspective de compétitivité et de durabilité. 
S ince the mid-1990s, a growing number of tourism destinations have opted for sustainable development strategies in order to face the economic, social and environmental issues of tourism in their territories (Bensahel and Donsimoni, 1999; Ritchie and Crouch, 2000; Van der Yeught, 2008). These destinations aim at achieving a satisfactory balance between economic prosperity, social equity and the preservation of their natural heritage in order to ensure visitor satisfaction within an intensely competitive context. Once engaged, the sustainable development process requires a thorough analysis of the complexity of territories and of tourism phenomena, which calls for a renewal of existing analytical frameworks through the cross-fertilization with the different disciplines.

This paper adopts a strategic management perspective. Its starting point is that destinations, just like firms, strive to be competitive. Its purpose is to answer the following question: How can organisations that manage tourism destinations produce strategic diagnoses that include both competitiveness and sustainability constraints? A resource-based strategic approach leads to the identification of rare resources and core competencies because they may generate sustainable competitive advantages (SCA) (Barney, 1991). From this perspective, the paper intends to build a typology of strategic resources that can help destination leaders achieve their competitive and sustainable objectives.

The research follows four steps. First, the paper examines the issues related to the sustainability and competitiveness of destinations and it suggests applying the resource-based view (RBV) framework to the question of sustainable destination management. Second, the methodological options are clarified and the three Mediterranean destinations under empirical study are presented: the Toulon Metropolitan Area (TMA) $)^{(1)}$, the Frioul Islands (both situated between the French Riviera and the Provence region), and the Cinque Terre National Park (on the Italian Riviera). Third, the enquiry identifies the criteria for a synthetic conceptual typology of sustainable strategic resources. Fourth, the following strategic diagnosis methodology is applied to the destinations under study to make sure it is supported by facts. The conclusion discusses the study's results.

\section{A RESOURCE-BASED APPROACH TO ANALYSE SUSTAINABILITY-DRIVEN TOURISM DESTINATIONS}

\section{The concept of sustainability}

The origins of sustainable development (SD), as a popularly engaged construct, can be traced back to the World Commission on Environment and Development Report (WCED, 1987), also known as Brundtland Report, which defines SD as a type of development that meets the needs of the present without compromising the ability of future generations to meet their own needs. The concept of SD was further popularised in 1992 thanks to the Rio Earth Summit, and to the Agenda 21 programme thereafter. This concept is both complex and multi-dimensional. It reaches beyond the contradiction summarised in the concept of eco-development (Sachs, 1980, 1997) by introducing a social dimension in the development issue. Basically, SD should aim at three main interconnected objectives (the three main 'pillars' of sustainability): robust economic growth, ecological viability and social equity. In accordance with the third objective, development should be concerned with issues of intragenerational equity (within a given generation, everyone should enjoy equitable access to resources and obtain their fair share of wealth) and intergenerational equity (for the benefit of future generations, the impacts of economic activities on natural capital should be controlled in order to ensure long-term economic growth and human survival itself). To address the social pillar of sustainability, Amartya Sen's notion of 'capabilities' (Sen, |99।) and John Rawls's 'theory of justice' (Rawls, 1987) could be of great interest in qualifying these activities that may lead to social sustainable development (Dubois et Mahieu, 2002; Rajaona Daka et Dubois, 2008).

The major applications of the concept of sustainability to the tourism industry date back to the 1990s and the first definitions of sustainable tourism were derived from the more general concept of SD. In 1995, the Charter for Sustainable Tourism of Lanzarote stipulated that 'a requirement of sound management of tourism is that the sustainability of the resources on which it depends must be guaranteed'. It also advocated the 'global management of resources so as to ensure their viability'.

More recently, the World Tourism Organization (2004) formulated a fairly explicit conceptual definition which insists on (i) the optimal use of environmental resources; (ii) the respect of the socio-cultural authenticity of host 
communities; (iii) the necessity for tourism activities to ensure viable and long-term economic operations, providing for the participation of all the relevant stakeholders, as well as strong political leadership to ensure wide participation and consensus building; and (iv) the ability to maintain a high level of tourist satisfaction.

This definition refers to 'sociocultural authenticity' without really identifying 'culture' as one of the pillars of sustainability. Yet, it may be useful to distinguish clearly between the 'cultural' and 'social' criteria of sustainability, if sustainable tourism is to be implemented.

\section{The competitiveness} of tourism destinations

Although the growth rates in the tourism industry are still high and should remain so in the future (WTO, 1999), escalating competition among destinations leads many of them to seek to improve their competitiveness while trying to take into account the long-term effects of tourism activities in a sustainable perspective (Ritchie and Crouch, 2000).

The concept of competitiveness and the related concept of competitive advantage are central to strategic management. Although, these are complex and multifaceted concepts that cannot lead to universally accepted definitions (Crouch and Ritchie, 1999), they are generally defined as the ability of an organisation to generate higher performance than its competitors. From a strategic point of view, the competitive advantage is 'sustained' when the value-creating strategy that generates it cannot be imitated or duplicated by any current or potential competitor (Barney, 1991, p. 102).

A significant part of strategic management literature has sought to identify competitiveness factors depending on the micro or macro level of the analysis. Porter (1980) built the value chain model to analyse the roots of competitive advantage at the firm's level and, to address competition at the national level, he proposed the diamond of competitive advantage (1990). Porter's advances paved the way for scholars dealing with the competitiveness of tourism destinations. Thus, Flagestad and Hope (200 I, p. 449) conceptualised a destination as a 'collection of interrelated economic activities', then they proposed 'the value fan' model in which they distinguished between the primary and the support activities that compose a destination's value chain. The primary activities are related to the creation of the destination's tourism products and to the transfer of value to the visitors (via hotels, restaurants, transport and other services), while the support activities contribute to the success of the primary activities, for example, by providing infrastructure, overall destination planning and the management of sustainability.

Building on Porter's diamond of national competitiveness (1990), Ritchie and Crouch $(2000,2003)$ developed a framework where they identified the basic sources of competitiveness and sustainability at the destination level. First, the authors made a distinction between comparative advantage, which results from a destination's factor endowments, both natural and created, and competitive advantage, which lies in these strategic processes that allow tourism resources to be used efficiently. Then, the authors presented a model which is based on five components: (i) 'supporting factors and resources'; (ii) 'core resources and attractors'; (iii) 'destination management'; (iv) 'qualifying determinants'; and (v) 'tourism policy'. Within this fifth component, they recommended an audit of the destination's existing tourism resources and capabilities before making strategic decisions.

Other publications, which are centred on the competitiveness of territories, offer methodologies that can help leaders define motivating and effective sustainable development strategies (LEADER, 1997, 1999; Teyssandier and Zysberg, 2000; Perret, Teyssandier and Marette, 200 I; Céron and Dubois, 2002; Perret, Teyssandier and Baldié, 2006).

The LEAder (1999) methodology opted for a comprehensive view of the competitiveness of rural territories engaged in sustainable evolutions. Prior to building a territory-development scheme, it recommended an analysis of its territorial capital in eight points: (1) the territory's physical resources and their management; (2) its culture and identity; (3) human resources; (4) competencies and know how; (5) governance; (6) economic activities; (7) markets and external relations; and (8) the territory's image and the public perception thereof.

The methodology proposed by Perret, Teyssandier and Marette (200I) gave priority to the actors of tourism and suggested that contradictory diagnoses be realised in order to take local diversity constraints into account. Sets of indicators are also thought to be useful to assess destinations' advances in terms of sustainable development (Perret, Teyssandier and Marette, 200 I; Céron and Dubois, 2002; WTO, 2004). However, experiments carried out in France have shown that leaders tend to adapt 
existing approaches to local requirements. Examples include the method proposed by Perret, Teyssandier and Marette (200I), which has never been thoroughly applied, and the contradictory diagnoses and batteries of indicators which have never been put to use (Perret, Teyssandier and Baldié, 2006).

As the literature review will show, the issues related to the strategic assessment of territories and destinations have already been built into different methodological constructions. However, how can we determine which listed criteria best apply to a given territory? Can these different approaches be combined into a single comprehensive and more manageable model without overlooking the destinations' inherent complexities? To answer these questions, this paper intends to draw lessons from the RBV.

\section{A conceptualisation \\ of tourism destinations \\ derived from the RBV}

Many definitions of tourism destinations have been proposed. Most of them focus on the territorial characteristics of the destination and on its capacity to attract and satisfy visitors. Flagestad and Hope (200 I) referred to Penrose's seminal work (1959) to define a destination as 'a bundle of resources', but they do not investigate further in this theoretical direction. Now, resources are central in a sustainable perspective and from a strategic point of view. Not only are they powerful attractive factors for the visitors, but they also influence the latter's satisfaction while they experiment the tourism products. So, this paper is founded on the main advances of the RBV.

In the resource-based perspec- tive, a tourism destination can be conceptualised as a collection of productive and human, tangible and intangible resources that may lead to a sustained competitive advantage (Penrose, 1959; Barney, 199|). The capital of resources available in the destination at any given time results from the investments that were made in the past (Dierickx and Cool, 1989) because most of the attractive resources of a destination, such as the historical and cultural heritage, the natural environment, the landscapes, the reputation for quality and so forth, have required time and human effort to achieve their current state. These specific assets are the cumulative results of the community's evolution over time and they play a crucial part in a destination's success. So, in accordance with the evolutionary principle of path dependency, the strategic choices made in the past may constrain the destination's evolution in the future (Dosi et al., 1990). In their attempt to explain why major companies' diversification strategies are consistent with their history, Dosi et al. (1990) observed that 'history matters', which means that the specificity of an organisation's assets influences its strategic evolution. However, the concept of path dependency does not foreclose future options because branching out remains a possibility through organisational learning and competitive pressure. The methodology of LEADER programmes (1999) emphasised the strategic importance of the territories' historical dimension because it reveals much about their identities, their present situations and their potential evolutions in the future.

In the RBV, the resulting heterogeneity between destinations may lead to a sustained competitive advantage if the resource system is valuable (it exploits opportunities and/or neutralises threats from the business environment), rare, imperfectly imitable, and if there cannot be strategically equivalent substitutes for it (Barney, 199I). In this perspective, the purpose of strategic management consists in identifying, preserving, using and creating these resources which may generate competitive advantages, precisely because they are rare (Arrègle, 2006).

\section{Methodology}

\section{Research design}

The empirical inquiry is based on a case studies research strategy, which is recommended in order to understand complex social phenomena when a 'why' or 'how' question is being asked about a contemporary set of events in unexplored research areas (Yin, 2003; Eisenhardt and Graebner, 2007). According to Yin (2003, p. 13), 'a case study is an empirical inquiry that investigates a contemporary phenomenon within its real-life context, especially when the boundaries between phenomenon and context are not clearly evident'. Multiple-case studies allow for the replication of the results while strengthening their external validity. Contrary to quantitative research strategies, the sampling of cases in qualitative research is not statistical, but analytical. In this study, the selection of cases was determined in order to enhance the generalisability of the diagnosis tools in the making: the selected destinations are all involved in sustainable tourism strategies and located in developed countries.

As far as data collection is concerned, case studies rely on mul- 
tiple sources of evidence with data needing to converge in a triangulation fashion (Yin, 2003). The data collected in this study come from many sources of evidence, as explained in table 1, which summarises the main steps of the research and the data collection procedure.

First, an exploratory step consisted in examining academic and institutional literature in order to understand what the destinations' managers understood by sustainability and which strategic assets best explain their strategic success. Second, three destinations engaged in sustainable strategies were investigated more thoroughly: the Toulon Metropolitan Area (TMA), the Frioul Islands and the Cinque Terre National Park. In each of the surveyed cases, the relevant resources of competitiveness and sustainability were identified. In reference to the different methodological approaches proposed in academic and institutional literature, the case studies led to the identification of three relevant criteria to classify sustainable strategic resources in order to make sure the proposed model could be properly applied.

Each type of resource was coded. Collected data were then restructured into matrixes and charts following the recommendations of Miles and Huberman (2003) (see models in section 3, tables 2 to 5). Then, the results were given to the destinations' leaders for them to amend, complement or validate.

\section{Case studies research}

The literature has been the main source of the empirical survey's exploratory phase. The World Tourism Organization, the European Commission, international conferences on sustainable tourism and scholarly research

\section{Table I Main steps of the research and data collection procedure}

\begin{tabular}{|c|c|c|}
\hline $\begin{array}{l}\text { Stages in the } \\
\text { research process }\end{array}$ & Periods of time & Data collection procedure \\
\hline $\begin{array}{l}\text { Exploratory study: } 20 \\
\text { synthetic case studies }\end{array}$ & Winter 2003-2004 & $\begin{array}{l}\text { Academic and institutional documentation: World } \\
\text { Tourism Organization (WTO, 2000), European } \\
\text { Commission (EU, 2000), research articles (Halme, 200 I), } \\
\text { international conferences (Chamonix Summit, 2000; } \\
\text { Rimini International Conference on Sustainable Tourism, } \\
200 \text { I), Internet }\end{array}$ \\
\hline $\begin{array}{l}\text { Pilot case study: } \\
\text { Toulon area (France) }\end{array}$ & $\begin{array}{l}\text { January 2004- } \\
\text { January } 2010\end{array}$ & $\begin{array}{l}\text { - Direct and participant observation of two European } \\
\text { sustainable tourism projects: Submed and Vistoria } \\
\text { - Regular interviews with the projects' managers } \\
\text { - Documentation and archival records } \\
\text { - Participation in five international steering committees } \\
\text { and exchange workshops }\end{array}$ \\
\hline $\begin{array}{l}\text { Laboratory study: } \\
\text { the Frioul Islands - } \\
\text { Marseilles area } \\
\text { (France) }\end{array}$ & $\begin{array}{l}\text { October 2005- } \\
\text { December } 2009\end{array}$ & $\begin{array}{l}\text { - Six interviews of three hours each with } \\
\text { the project's managers } \\
\text { - Documentation and archival records } \\
\text { - Participation in seven participative public meetings }\end{array}$ \\
\hline $\begin{array}{l}\text { Exemplary case } \\
\text { study: the Cinque } \\
\text { Terre National Park } \\
\text { (Italy) }\end{array}$ & $\begin{array}{l}\text { November 2003- } \\
\text { March } 2007\end{array}$ & $\begin{array}{l}\text { - Three visits of the destination } \\
\text { - Documentation and archival records } \\
\text { - Interviews via e-mail } \\
\text { - Two face-to-face interviews with the chairman } \\
\text { of the Park } \\
\text { - Two face-to-face interviews and visits with the assistant } \\
\text { of the chairman }\end{array}$ \\
\hline
\end{tabular}

articles provided twenty significant examples of strategies based on sustainable tourism. The authors of the support documents generally considered that these strategies were successful. They described the driving forces behind each project and they presented the results that had been obtained: the creation of new sustainable tourism activities, the improvement of the quality of tourism services, the rehabilitation of traditional settlements, the protection of the natural environment, the management of networks to implement sustainable tourism, etc. Some of these documents refer- red to difficulties in managing the networks. However, most of them rather focused on the general attainments than on specific quantitative results. Because this part of the study was based on a literature review, obtaining more accurate information proved difficult. As a remedy to these shortcomings, an in-depth analysis was carried out, between 2004 and 2010, on three Mediterranean destinations while they were implementing sustainable development strategies.

- The PILOT CASE: The Toulon Metropolitan Area (TMA). In this paper, TMA stands as the pilot case because the author of this 
article was given permission to participate in the sustainable tourism projects (Submed and Vistoria) during their implementation, between January 2004 and October 2006. She kept in regular touch with the programme leaders thereafter. TMA was created in January 2002 to meet the requirements of several French national devolution acts, which encourage the development of joint-venture partnerships between cities. Eleven municipalities in the Toulon area agreed to form the TMA cluster that extends from the Mediterranean seaboard to the Provence region. In January 2004, the new entity was still unfamiliar to the population and it needed financial funds to invest in local development policy. In this context, the strategy managers decided to join two European sustainable tourism programmes (Interreg III B and C): Submed, to promote sustainable scuba diving activities in the Mediterranean Sea, and Vistoria, to develop tourist itineraries highlighting scenic and historical resources. Within the Vistoria programme, TMA was in charge of designing methods to promote the historical and natural heritage of the nine European participating destinations. The investigation resulted in diagnosis tools that assess the strategic assets of the destination from a sustainable point of view. Thereafter, this diagnosis framework was tested and improved thanks to the Frioul Islands case.

- The laboratory case: The Frioul IsLANDS. The Marseilles urban community is involved in an ambitious sustainable development strategy for all its seaboard areas. The programme includes the Frioul Islands where the local authorities intend to develop sustainable tourism projects. Given the small size of this archipelago (two hundred hectares), the Frioul Islands were selected as a laboratory case for this research experiment. Since 1971, the archipelago has been managed by the public authorities of the Marseilles Township after private investors failed to manage the site properly. One hundred people live full-time on the islands and they need to reach the continent in order to benefit from different kinds of amenities like schooling, medical services, employment, shopping, and so on. Although the tourists and local inhabitants are really fond of the place, tourism facilities are scarce. Most visitors access the archipelago on their private yachts and they sleep on board. The local authorities hope to make the Frioul Islands a show-case of Marseilles' know-how regarding sustainability and, with that intent, they decided to organise a decision-forum where citizens, business managers, association leaders and public institution leaders were invited to express their views. This case study permitted the completion of the methodology of the pilot case's strategic diagnosis, especially in its environmental and social dimensions. In the following stage of this survey, the tools of the strategic diagnosis have been tested and refined on the Cinque Terre National Park, which is one of the most advanced sustainable tourism ventures examined in this paper.

- The exemplary case: The Cinque Terre National Park (CTNP). The Cinque Terre National Park (CTNP) originally featured in the exploratory study. It provided a wealth of informa- tion that justified further investigation. The local authorities agreed to be interviewed, first by e-mail, then in face-to-face meetings. This case is qualified as 'exemplary' because the destination's leaders have reached ambitious sustainability objectives since the creation of the park in 1999, thanks to an original governance system. The CTNP is situated on the Ligurian sea-board, south of the port of Genova. This protected natural area was included in the UNESCO environmental and cultural world heritage list in 1997. It qualified as a protected marine area in 1997 and as a national park in 1999 . The cliffs fall vertically into the Ligurian Sea and the rocky coastline stands out as one of Italy's most attractive landscapes. The scenery was modelled by men who, over a thousand years, painstakingly transformed the steep slopes into farming terraces and vineyards where the famous Sciachettrà wine is produced. Starting in the 1960 s, modern roads encouraged young people to leave the five isolated villages to find jobs in the neighbouring cities and brought more tourists. However, as farming activities disappeared, the area's terraced landscape quickly fell into decay, putting inhabitants and tourists at risk. The local authorities' reaction was to develop a sustainable tourism strategy with the aim of creating jobs in order to encourage the inhabitants to remain in the villages and of controlling the impacts of tourism. Ten years after the creation of the protected area, the local authorities have already reached many of their initial objectives. The Park's chairman is encouraged by the success of his strategy and hopes 'to sustain the development of the area over one or two centuries at 
least $^{(2)}$. The park's outstanding achievements permitted the completion of the classification system of strategic resources, especially in its economic and social dimensions.

\section{A CONCEPTUAL TYPOLOGY OF SUSTAINABLE STRATEGIC RESOURCES}

The first step when analysing a destination's strategy is to list and measure all those resources which are relevant from a competitiveness and sustainability perspective. Because of the large number of proposals found in the literature, it is vital to determine which criteria best apply to the destinations under study. This paper selects the three following criteria.

\section{The first criterion of resources classification: the four pillars of tourism sustainability}

Experts generally identify the three pillars of sustainability as the economic, the social and the environmental pillars. However, the case studies have revealed that a fourth pillar, the cultural one, is of crucial importance to measure a territory's path dependency, to define its identity and to determine its strategic position. Therefore, although the two dimensions are generally merged in the literature (WTO, 2004), the typology of resources proposed in this paper distinguishes between the social and cultural dimensions and specifies their different contents.

The economic and environmental dimensions are the most widely quoted in the exploratory case studies. The economic pillar is illustrated through several activities, some of which are recurrent in the case studies: new profit-generating tourism products, quality labels for tourism businesses, job-inducing activities, additional income in poor areas, extension of the tourist season, creation of networks to implement sustainable tourism.

The environmental pillar is also central in most exploratory case studies, mainly in relation to the economic one. Environmental sustainability may assume different forms, such as new environmentfriendlier activities, eco-labels, environment management, waste reduction and energy-saving programmes, renewable energies, water management, the preservation of the natural heritage, environment-friendlier transport, human-powered mobility, the reduction of pollution and greenhouse gases, landscape conservation and soil erosion control.

As regards the social and cultural dimensions, official definitions do not clearly distinguish between the two (cf. supra). Yet, both notions appear to be sufficiently significant to justify separate approaches and specific clarifications. Culture refers to symbols. In the field of management science, Hofstede (200 I, p. I) defines culture as a 'collective programming of the mind', which 'manifests itself not only in values, but in more superficial ways: in symbols, heroes, and rituals'. The mental programming processes of a given human group cannot be observed in daily life, but they can be captured through the artefacts produced by its members. Thus, in tourism destinations, cultural sustainability refers to different activities which aim at promoting the community's artefacts and values. In the exploratory case studies, such activities may be: preserving the historical and architectural heritage, restoring traditional settlements, promoting the community's arts and crafts, marketing local food and wine, and creating special events and entertainments. These cultural assets contribute to a destination's competitiveness and sustainability, because they make it more attractive and unique when compared to rival destinations.

As far as the social pillar is concerned, we may resort to three concepts developed by Amartya Sen and John Rawls in their attempt to improve social justice: accessibility and capability enhancement (Sen, 1991), and equity (Rawls, 1987). In our framework, these concepts may be applied to various target groups: the tourists, the local communities, and the employees and the managers of tourism companies. The accessibility criterion is derived from Sen (1991), who frequently identifies free movement (and safety and security as its prerequisites) as one of the basic human rights. Now, because many people are deprived of tourism consumption by health or financial problems, the accessibility criterion has been selected to account for destinations' efforts to respect their visitors' rights to unrestricted access, especially when vulnerable visitors are concerned. For the disabled, access can be made easier thanks to appropriate infrastructure and services. For instance, the CTNP has designed specific activities for handicapped visitors. For financially-challenged persons, cheap accommodation may facilitate access to tourism destinations. For example, the only referenced accommodation provider in the Frioul archipelago (except rentals) is a non-profit association which rents dorms to visiting groups. 


\section{Table $2 \cdot$ Economic strategic resources}

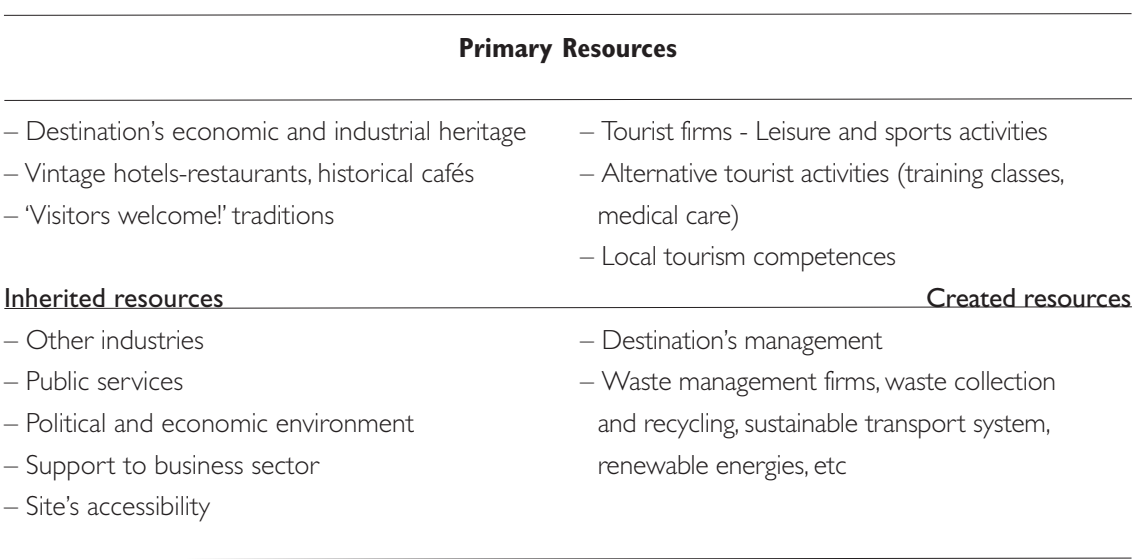

Support Resources

Table 3 - Environmental strategic resources

\begin{tabular}{ll}
\hline & Primary \\
& Resources \\
\hline - Climate & - Natural parks and protected areas \\
- Topography & - Zoos, public aquariums, gardens and \\
- Geomorphology & botanical gardens \\
- Hydrography & - Rambling paths and cycling trails \\
- Coastal areas & - Underwater trails \\
- Wildlife - Flora & \\
Inherited resources & \\
- Minerals, raw materials and energy & - Land use \\
& - Renewable energies \\
& - Recycling \\
& - Sustainable transport
\end{tabular}

Support Resources

The capability-enhancement criterion is also derived from Sen (|99|): the aim of any economic policy should be to develop people's capabilities to expand their freedom. Educational programmes and vocational training fulfil these objectives and enable participants to make a new start in life. The case studies show that the tourists, the local community and the people working in the tourism industry may benefit from edu- of distributive justice proves to be particularly crucial in the tourism industry. For example, in the Cinque Terre case, profits from tourism generated through the park's turnover pay for 'Quality of Life' initiatives.

\section{The second criterion of resources classification: the inherited or created character of the resources} The second criterion used to classify strategic resources aims at identifying the destinations' path dependencies in order to determine future strategic options consistent with their history. This criterion was developed during the Vistoria project (pilot case) with the help of several historians. Their mission was to design a common methodology to promote the natural and historical resources of the partner destinations. The approach they suggested was to list and to date the area's different cultural resources and to explain how the landscapes had changed in history. Tourist discovery routes were developed from these data with two objectives: first, they were to publicise the community's identity by promoting its cultural artefacts and its 'uniqueness'; second, the routes' visitors could enjoy new experiences by discovering the destination's authentic heritage. The purpose of the second classification criterion, drawn from the Vistoria historians' approach, is to capture the evolutionary processes that have generated the destination.

To understand what Penrose (1959) called 'the direction of expansion', it is vital to measure at any given time the stock of the 'inherited resources' that are transmitted by past generations. Now, the mix of the resources which are available at any given time within a destination results from flows and 
stocks dynamics (Dierick $x$ and Cool, 1989) that require the development of new resources and strategies. So, the second classification criterion separates 'inherited resources' from 'created ones', as suggested by Ritchie and Crouch (2003, p. 23). Inherited resources may be defined as the natural and historical material passed on to the living generations by the path dependency process. These inherited resources fit precisely into the 'resource endowments' category as defined by Ritchie and Crouch $(2000,2003)$. They include both natural resources, such as weather characteristics, geography, hydrography, wildlife and flora, etc., and resources crafted by past generations such as old industrial plants, historically-significant businesses, local traditions, typical architecture, historical and cultural attractions, etc.

On the other hand, created resources result from the ongoing activities of present generations and they widely depend on their competences. In our framework, created resources incorporate competences into a set of elementary resources so as to develop sustainable tourism. For example, wildlife and flora are classified as environmental inherited resources whereas protected areas and zoos fall into the created resources category since they resort to scientific know-how to manage, at the present time, the destination's natural heritage. Similarly, the destination's old industrial plants and historically-significant businesses (for example vintage hotels, historical cafés) are classified as economic inherited resources because they are not competitive tourist activities as such. To qualify as created resources, they need to be combined with human knowledge, capital resources and tourism compe-

\section{Table 4 - Social strategic resources}

\begin{tabular}{ll}
\hline Primary & Resources \\
\hline & \\
& - Services and benefits resulting \\
& from social tourism \\
& - Facilities for the disabled \\
& \\
\hline Inherited resources & - Educational programmes and \\
- General regulation of tourism professionals & professional training \\
- General social conditions & - Fair distribution of tourist profits \\
- Safety and security & - Youth insertion building programmes \\
- Community's social cohesion & - Accommodation for seasonal workers \\
& - Anti-poverty programmes
\end{tabular}

Support Resources

\section{Table 5 • Cultural strategic resources}

\begin{tabular}{lc}
\hline & Primary Resources \\
\hline - Site's history and archaeology & - Museums, art and exhibition centres \\
(including myths and legends) & - Special events (festivals, tournaments, shows, \\
- Pilgrimage centres & sports contests) \\
- Architecture & \\
- Local languages and dialects & \\
- Culinary traditions & \\
- Local arts and crafts & \\
Inherited resources & \\
- Local celebrities & \\
- Listed buildings of character & \\
- Customs and traditions & \\
- Religious worship &
\end{tabular}

Support Resources

tences to contribute to the destination's competitiveness (Ritchie and Crouch, 2003). Admittedly, certain cases of hybridisation may occasionally occur and blur the distinction between the two resource categories. However, because developing resources and competences is a dynamic process, resource hybridisation is generally temporary and does not justify giving up the distinction altogether. This distinction introduces a dynamic element in the basically static classification system. It clearly brings out the path dependency of the destination, and helps define new strategic options which are consistent with past choices.

\section{The third criterion of resources classification: the primary or support resources}

The third classification criterion 


\section{Table $6 \bullet$ The principal strengths and weaknesses of TMA (Toulon Metropolitan Area)}

\begin{tabular}{|c|c|c|c|}
\hline \multicolumn{2}{|r|}{ StRENGTHS } & \multicolumn{2}{|c|}{ WEAKNESSES } \\
\hline \multicolumn{4}{|c|}{ Economic strategic resources } \\
\hline $\begin{array}{l}\text { IPR: } 2 \text { mature tourist attraction } \\
\text { zones (territory's eastern and } \\
\text { western zones); Leading } \\
\text { French naval base; Freight and } \\
\text { passenger terminals }\end{array}$ & $\begin{array}{l}\text { CPR: Beach and boating activities, } \\
35 \text { registered scuba diving centres, } \\
\text { I } 3 \text { marinas, } 2 \text { fully-equipped beach resorts, } \\
\text { numerous accommodation facilities (about } \\
400 \text { hotels and } 500 \text { restaurants) }\end{array}$ & $\begin{array}{l}\text { IPR: Tourism experience must be } \\
\text { strengthened in eastern and } \\
\text { western zones, and developed in } \\
\text { central zone }\end{array}$ & $\begin{array}{l}\text { CPR: Substandard accommodation } \\
\text { (50\% of facilities are open air), } \\
\text { Destination's poor brand image } \\
\text { (lack of quality and professionalism) }\end{array}$ \\
\hline
\end{tabular}

CSR: Favourable economic and political context, Sea-oriented economic

CSR: Complex and multi-layered management structure of destination

cluster; Easy access

\section{Social strategic resources}

CPR: Social and non-for-profit tourism (30 facilities); Ongoing programme CPR: Limited access equipment for physically-challenged visitors to facilitate access for physically-challenged visitors

CSR: Vocational schooling in hotel and tourism management (secondary level)
CSR: Lack of accommodation for seasonal workers; Limited higher education training in hotel and tourism management

\section{Environmental strategic resources}

IPR: Sunny and windy weather CPR: 'Natura 2000' areas - Protected conditions; Limited rainfall;

Marshlands, islands and archipelagos; Rich land and underwater flora (posidonia meadows) marine areas and Port-Cros National Park (1963), Institut Océanographique Paul Ricard (1966); Protected zones and conservation areas for birds; Botanical gardens; I zoo for feline species; Beaches awarded 'Blue Flag' European label; Extensive mileage of hiking paths; 2 under-water discovery routes in 2004 ( 4 by end 2006 )
CPR: Heterogeneous distribution of natural assets on territory CSR: Real estate pressure on available land; Limited renewable energy initiatives

\section{Cultural strategic resources}

$\begin{array}{ll}\text { IPR: Archaeological and } & \text { CPR: I5 museums and art centres; } 50 \\ \text { historical resources; Toulon is a } & \text { annual cultural events; 7,500-seat concert } \\ \text { centre of military traditions - } & \text { hall; Chateauvallon cultural centre }\end{array}$

CPR: Cultural events restricted to summer season centre of military traditions numerous WW2 memorials; pilgrimage sites; Rich diversity of fortified strongholds;

Provence's world-famous cuisine and sea-food recipes

ISR: local celebrities (Jean Aicard [novelist], Félix Mayol [music-hall singer], Raimu [actor]).
ISR : Toulon's image is closely related to its naval base with a somewhat negative impact on tourism

IPR: Inherited primary resources • CPR: Created primary resources • CSR: Created support resources • ISR: Inherited support resources. 
is derived from Porterian terminology. It helps distinguish between 'primary' and 'support' resources. As seen in the literature review, in order to analyse the roots of competitive advantage at the firm's level, Porter (1980) built the value chain model where he distinguished between the primary and support activities and Flagestad and Hope (200I) used the Porterian distinction to conceptualise a destination's value chain (the valuefan model). This paper suggests applying the Porterian terminology not simply to economic activities but also to environmental, social and cultural resources. In our construction, the primary resources characterise the major assets of a destination as a tourist attraction. These assets create value for visitors either as unique attractions or combined with others. On the other hand, support resources relay and complement the attractive power of the primary resources. They often play a vital role in the production of sustainable value without being attractive themselves. From that perspective, tourist accommodation and entertainment facilities are classified as 'economic created primary resources', while ancillary collective services, which are used by tourists but are not part of the tourism industry (public transport, banking services, medical care) fall into the 'economic support resources' category. These support resources only create value for visitors when combined with primary resources.

The various sustainable tourism strategic resources can be listed and grouped following the format proposed in tables 2 to 5 , whose content is fed by the case studies. The typology is the groundwork of the strategic diagnosis methodology.

\section{The SUSTAINABLE STRATEGIC DIAGNOSIS OF DESTINATIONS}

The second step when analysing a destination's strategy is to build the destination's diagnosis by designing a matrix of its strengths and weaknesses as exemplified in tables 6 to 8 . Then, the destination's strengths and weaknesses clearly appear, the path dependency can be identified and strategic options can be formulated in order to implement successful projects.

\section{The sustainable strategic diagnosis of TMA}

In the TMA case study, the territory's heterogeneity calls for a strategy reinforcing the attractiveness of the more deprived townships, while consolidating the existing assets of the two more mature tourism centres (in the eastern and western parts of the territory). These two poles enjoy rich cultural and natural assets (on land and sea). They also benefit from the scientific expertise acquired in oceanographic fields of study by the National Park of Port-Cros (the first French sea park opened in 1963) and by the Institut Océanographique Paul Ricard (established in 1966). However, tourism facilities are unevenly distributed and generally substandard (mostly open air camping sites). The destination's brand image is poor (little value for money) and its management is multi-layered and inefficient.

The results of the strategic analysis handed over to the territory's advanced planning committee recommended four non mutually exclusive operational options: (1) set up theme routes to promote the territory's natural resources, especially in the neglected areas; (2) improve the positioning of the site as a sea destination; (3) increase the territory's 'social' sustainability (facilitate access for physically-challenged visitors, help seasonal workers find accommodation, develop higher education); and (4) delayer and reorganise the destination's management structure.

Understanding the territory's history reveals some of its liabilities and clarifies why certain choices were made. The study shows that Toulon's difficulties in developing as a seaside resort date back to the $17^{\text {th }}$ century, when Colbert decided to turn the town into France's premier naval base while Marseilles was to specialise in commercial shipping. This political decision is at the beginning of a path dependency that still has far-reaching effects on the current developing prospects of the two main French Mediterranean sea ports. At present, the French Navy is relinquishing a growing number of its properties in the Toulon Bay Area and the civilian authorities are taking over many fortified strongholds from the military. These forts (there are about thirty of them) add fresh value to the destination's cultural heritage. Since its inception in 2002, TMA has invested heavily in order to restore them one by one and has included them into visitors' sightseeing programmes. This has come as a preliminary step to the Vistoria programme, which aims at channelling evenly the flows of visitors over the territory's area thanks to new tourism theme routes.

The territory's recent history also shows that developing scuba diving activities is consistent with the territory's past. Indeed, the 


\section{Table 7 - The principal strengths and weaknesses of the Frioul archipelago}

\begin{tabular}{|c|c|c|c|}
\hline \multicolumn{2}{|c|}{ StRENGTHS } & \multicolumn{2}{|c|}{ WEAKNESSES } \\
\hline \multicolumn{4}{|c|}{ Economic strategic resources } \\
\hline $\begin{array}{l}\text { CPR: I } 0 \text { restaurants, I accommc } \\
\text { activities }\end{array}$ & ion facility for groups, boating & $\begin{array}{l}\text { IPR: Lack of tourist-reception } \\
\text { traditions }\end{array}$ & $\begin{array}{l}\text { CPR: Limited accommodation } \\
\text { facilities }\end{array}$ \\
\hline $\begin{array}{l}\text { ISR: I certified organic fish farm; } \\
\text { I shipyard; I waterworks station }\end{array}$ & $\begin{array}{l}\text { CSR: I new environment-friendly } \\
\text { ferry service }\end{array}$ & $\begin{array}{l}\text { ISR: Inadequate collective services; } \\
\text { I (expensive) local shop; Limited } \\
\text { access }\end{array}$ & $\begin{array}{l}\text { CSR: No promotion; } \\
\text { Environmentally-restricted } \\
\text { construction zone }\end{array}$ \\
\hline
\end{tabular}

Social strategic resources

CPR: Social and non-for-profit tourism; Marine activities for school groups CPR: Facilities inadequate for physically-challenged visitors

CSR: Youth insertion building programmes; Leisure activities for deprived CSR: Lack of accommodation for seasonal workers teenagers; Numerous associations in charge of natural protection and entertainment activities

\section{Environmental strategic resources}

\begin{tabular}{|c|c|c|c|}
\hline $\begin{array}{l}\text { IPR: Sunny and windy weather } \\
\text { conditions; Limited rainfall; Rich bird }\end{array}$ & $\begin{array}{l}\text { CPR: Qualified as 'Natura 2000' site; } \\
\text { Conservation area for birds; }\end{array}$ & $\begin{array}{l}\text { IPR: No fresh water resources on } \\
\text { islands }\end{array}$ & $\begin{array}{l}\text { CPR: Summer over-crowding has } \\
\text { negative impact on environment }\end{array}$ \\
\hline $\begin{array}{l}\text { wildlife; Rich land and underwater } \\
\text { flora (posidonia meadows) }\end{array}$ & $\begin{array}{l}\text { Protected zone; Developing } \\
\text { seaboard national park }\end{array}$ & & \\
\hline
\end{tabular}

Cultural strategic resources

IPR: Underwater archaeological heritage; Historical monuments (Hôpital Caroline; Château d'lf); Legends and fiction related to the Château d'If (Le comte de MonteCristo $^{(3)}$, L'Homme au masque de fer( ${ }^{(4)}$ )
CPR: Hôpital Caroline used as a venue for numerous cultural shows and exhibitions in the summer; Château d'If museum; Developing intercultural centre

CSR: Volunteer building programmes to promote destination's heritage

IPR: Inherited primary resources $•$ CPR: Created primary resources • CSR: Created support resources • ISR: Inherited support resources.

world's first scuba diving experiments were carried out in the area by Cousteau, Taillez and Dumas as early as 1943. Moreover, since the 1960s, the National Park of Port-Cros and the Institut Océanographique Paul Ricard have achieved significant scientific advances into the knowledge of marine life and have designed effec- tive policies for its protection.

Consequently, the study confirms the relevance of the Vistoria and Submed programmes.

The Vistoria programme resulted in a series of additional theme tours which aim to promote the destination's various assets (gardens, landscapes, health care centres, 'Belle Époque' walk paths, artists and painters' favourite spots, vintage buildings). The classification of the cultural resources, which is presented in this article, was included in the common methodological framework of the programme's European partners. Similarly, Submed sponsored the creation of two underwater marine life discovery paths, fitted sixteen 
scuba diving sites with environment-friendly mooring equipment and contributed to the design of environment-awareness campaign backups. In 2010, Submed's success and fame among tourism operators encouraged TMA to propose expertise transfers to other countries as an international cooperation scheme. A Submed 2 application file is currently being processed by the French and European authorities. Nonetheless, certain issues related to the destination's social and managerial dimensions could not be studied in depth since they fall under the jurisdiction of higher administrative echelons than that of TMA.

\section{The sustainable strategic diagnosis} of the Frioul area

In the case of the Frioul area, the economic dimension has clearly been neglected. Since the 1970s, the Marseilles municipality has managed the archipelago and favoured the social, cultural and environmental dimensions while downplaying economic development. Except for a single social tourism structure, accommodation is scarce and the marina is inadequate to meet present needs. However, any potential development venture may affect the environment and faces strong opposition. On the social level, the Marseilles municipality encouraged many non profit associations to develop youth educational programmes and work reinsertion initiatives for deprived persons. On the environmental level, the site has benefited from a preservation scheme managed by the CEEP, a conservatory devoted to the study of the Provence area ecosystems, which has carried out several surveys of the archipelago's wildlife and flora. On the cultural level, several work insertion programmes help restoring the site's historical heritage, notably the Lazaret and the Caroline hospital which used to be Marseilles' quarantine confinement stations. In the summer, cultural events are staged on the Caroline site, although not on a regular basis.

The analysis handed over to the Frioul Project managers identified three prospective evolutions: (1) develop tourism accommodation; (2) develop sea and land ecotourism activities; and (3) improve the management of cultural attractions. For political and financial reasons, delays have affected the project. Ongoing negotiations concerning the Parc National des Calanques (a sea-board national park project) may jeopardise new accommodation developments, while plans for an International Conference Centre may turn the Caroline site into a vibrant cultural centre.

The sustainable strategic diagnosis of the Cinque Terre National Park

In the park's tourism development strategy, the four dimensions of sustainability are taken into account. The strategic analysis reveals the park's numerous assets but it also pinpoints some weaknesses that may lead to future developments.

The site's major attractiveness results from a centuries-old combination of nature and culture whose unique blend determines the park's strategic orientations. The Cinque Terre has been listed in the World Heritage List as a 'cultural site of outstanding value, representing the harmonious interaction between people and nature to produce a landscape of exceptional scenic quality' (UNESCO, 1997). However, if the territory had not been intensively protected, its natural path dependency would probably have led to its demise. Although tourism was first perceived as a risk factor, it has become a top priority to boost local economic development.

Every year, more than one million tourists visit the park, mainly for hiking and scuba diving. Most tourism businesses $(90 \%$ of tourism structures) are involved in the eco-quality brand processes, which provide for routine assessment of visitors' satisfaction, and agriculture remains the mainstay of the local economic development.

As far as the natural environment is concerned, much has been achieved: preserved areas, organic farming and ecotourism activities. Car driving is banned in the villages: visitors walk or use the train or electrical buses. Nevertheless, the park's office must improve waste management procedures and the inland access for tourists who generally remain on the coast.

The 'Quality of Life' programme is a plus in the social dimension. The funds generated by tourism pay for free public transport for residents, old age care, a crèche and a school. The CTNP has also designed specific activities for handicapped visitors: an underwater marine life discovery trail can be accessed by blind persons; sea outings are proposed for mentally incapacitated children, where they can communicate with the dolphins that live freely in the sea mammals marine sanctuary; and a horse-riding club hires qualified instructors who look after certain mentally or physically handicapped visitors. The park's most popular rambling path, la Via dell'Amore, is wheelchair acces- 


\section{Table 8 - The principal strengths and weaknesses of the Cinque Terre National Park}

\begin{tabular}{|c|c|c|c|}
\hline \multicolumn{2}{|c|}{ StRENGthS } & \multicolumn{2}{|c|}{ WEAKNESSES } \\
\hline \multicolumn{4}{|c|}{ Economic strategic resources } \\
\hline $\begin{array}{l}\text { IPR: Vineyards (premium wines), } \\
\text { fishing }\end{array}$ & $\begin{array}{l}\text { CPR: } 200 \text { accommodation facilities } \\
\text { but few hotels; Organic farming } \\
\text { development initiatives; Eco-friendly } \\
\text { tourism activities (hiking and scuba } \\
\text { diving) }\end{array}$ & $\begin{array}{l}\text { IPR: Tourism development is recent; } \\
\text { Site marked by long-term isolation } \\
\text { and country life traditions }\end{array}$ & $\begin{array}{l}\text { CPR: Opportunistic landlords } \\
\text { (difficult to control quality and } \\
\text { prices) }\end{array}$ \\
\hline $\begin{array}{l}\text { ISR: Traditional access by rail recently } \\
\text { completed by road network; Park } \\
\text { management entity is politically } \\
\text { independent }\end{array}$ & $\begin{array}{l}\text { CSR: Local eco-friendly transport } \\
\text { network; Destination's management } \\
\text { unit is well-structured and efficient }\end{array}$ & & \\
\hline
\end{tabular}

\section{Social strategic resources}

CPR: 2 youth hostels; Numerous initiatives for the handicapped

CPR: Costly destination despite park's best efforts

CSR: Effective support for tourism operators; 'Quality of life' programme

CSR: Lack of accommodation for seasonal workers

financed by tourism revenues

\section{Environmental strategic resources}

IPR: Warm and rainy climate;

Remarkable terraced landscapes;

Rich land and underwater flora
CPR: Protected area since 1985 ,

National park since 1999; Qualified

as 'Natura 2000' site; I botanical

garden; I underwater discovery

route; $65 \mathrm{~km}$ of hiking paths
CSR: Eco-friendly transport systems (on land and sea); Environment awareness programmes for schools; Ongoing alternative energies development projects
IPR: Unstable geological structures; CPR: Limited water activities

Frequent landslides and high ground

collapse risk

CSR: High demographic density on 10\% of territory; Slow development of refuse recycling schemes

\section{Cultural strategic resources}

IPR: Enduring catholic traditions;

Numerous tales and legends; 5

religious sanctuaries and pilgrimage

routes; Fortified ruins; Several local

dialects
CPR: Revival of forgotten traditional recipes; Restaurants promote organic produce and local wines; Centuriesold cultural and religious festivals
CPR: No museum; 2 art centres; Park-sponsored art exhibits
ISR: Resilient community values: tolerance and mutual help
CSR: Monumental frescoes by Silvio

Benedetto expressing traditional life scenes

IPR: Inherited primary resources • CPR: Created primary resources • CSR: Created support resources • ISR: Inherited support resources. 
sible and is equipped with lifts to facilitate the access of disabled visitors to the coastal trail network. However, the social dimension is negatively affected by the park's economic conditions because the Cinque Terre remains an expensive destination for people of modest means. Cheap accommodation is scarce - there are two youth hostels in all - and no accommodation is available for season workers. Finally, the cultural dimension is limited to local history, cooking and winemaking. The park has no museum. The chairman sees the park as a hothouse of sustainable projects, but he is deeply concerned by the park's weaknesses: in his view, a lot has been achieved but much remains to be done.

In recent years, as tourism was developing globally, a significant number of destination leaders have been increasingly concerned about competitiveness and sustainability issues. They have seen them both as necessary to implement the inevitable mutation towards sustainability. In response, a research movement has emerged in order to improve the strategic management of sustainability-driven destinations and territories, and several models have been proposed in this perspective (LEADER, 1997, 1999; Flagestad and Hope, 200 I; Perret, Teyssandier and Marette, 200 I; Ritchie and Crouch 2000, 2003). However, the proposed methodologies are not innocent. They generally stem from unexplicit theories and, as the French experiments have demonstrated, it's up to each territory to define its own method depending on available competences and local characteristics (Perret, Teyssandier and Baldié, 2006).
This paper's purpose is to clarify the theoretical basis of the study in order to design a strategic analytical method for the destinations under study. The method is a toolbox for leaders to (1) produce decision tools adapted to sustainable development strategies; (2) put the concept of sustainable tourism into practice; and (3) identify the path dependency of each destination.

First, this article builds a strategic diagnosis method that offers a typology of strategic resources, which are regrouped according to three classifying criteria: (1) the relevant pillar of sustainability; (2) the created or inherited character of the resource; and (3) the primary or secondary function of the resource. Then, the strategic diagnosis can be carried out by reshuffling available data in a matrix of the strengths and weaknesses of the destination.

Second, the method provides destination leaders with strategic management tools which give them a useful framework to put the complex concept of sustainable tourism into practice. Thanks to the cross-fertilisation of RBV and the principles of sustainability, the methodology fosters the implementation of sustainable tourism projects and the mutation of tourism destinations into sustainable development ventures. Depending on their available resources, destination authorities can opt for holistic sustainable approaches (the cases of the Cinque Terre and of the Frioul), or focus on one particular dimension (the Submed and Vistoria programmes in TMA). The method takes into account the foreseeable effects of each decision from the strategy's inception phase. Decision makers can then keep track of their resources at any time $\mathrm{T}$, and compare them with the ongoing project, and the actual achievements in $\mathrm{T}+1, \mathrm{~T}+2$, etc. Indeed, a long-term assessment of strategic options is vital in a sustainable perspective and batteries of indicators may be used at this level.

Third, the methodology helps identify the destination's path dependency in two ways: (1) by distinguishing between inherited and created resources; and (2) by identifying culture as one of the basic pillars of tourism sustainability. The methodology includes the destination's historical dimension in the analysis and, by doing so, it discloses which of the past choices influence the present strategic options. As the case studies clearly show, once this information is taken into account, the site's evolutionary path may be modified thanks to a determined strategic policy and suitable governance practices.

In spite of its advances, this study suffers from limitations and further research would be necessary for a more thorough study of the subject. First, on the methodological level, this exploratory research resorts to several case studies in order to capture the complexities of an emerging phenomenon (Yin, 2003). The strategic diagnosis methodology was built following an iterative process that required data collecting in different sites. The three major cases are studied in a longitudinal way and they have many common characteristics. They are European- and Mediterranean- based and are managed by their communities under the supervision of public authorities. Nevertheless, each destination has unique features and must resort to specific means to achieve its proper sustainable objectives. Further investigations invol- 
ving other destinations would be necessary to achieve the statistical generalisation of the results. In particular, studying the case of resource-deprived areas would be of interest. As it stands, the present framework is flexible enough to accommodate a larger sample of countries.

Second, on the theoretical level, the method is still largely descriptive and the processes whereby a competitive advantage is gained should be studied in greater depth. Now, the Cinque Terre case reveals that the governance system is a crucial success factor. The governance issue is included in the proposed model (support to the business sector, destination's management), but the subject requires further research. The resource-based strategic diagnosis method proposed in this article is just the starting point of further research efforts to study the generative processes of competitive advantages that observe the principles of sustainability.

(I) This is a translation for 'Toulon-ProvenceMéditerranée', the French name given to a group of municipalities that cluster around the City of Toulon.

(2) Interview with the chairman of the park, march 2007.

(3) A novel by Alexandre Dumas.

(4) The Man in the Iron Mask.

\section{RÉFÉRENCES BIBLIOGRAPHIQUES}

Jean-Luc Arrègle, "Analyse 'resource based' et identification des actifs stratégiques", Revue française de gestion, 32 (I 60), 2006

[1996], pp. 24 I- 159.

Jay B. BARNEY, "Firm resources and sustained competitive advantage", Journal of Management, 17 (I), I991, pp. 99-1 20. Liliane BENSAHEL et Myriam DONSIMONI, Le Tourisme, facteur de développement local, Presses Universitaires de Grenoble, 1999. Jean-Paul CÉroN et Ghislain DuBOIs, Le Tourisme durable dans les destinations. Guide d'évaluation, Presses universitaires de Limoges, 2002.

Chamonix Summit, Proceedings, 2000.

Geoffrey I. CROUCH et JR Brent RITCHIE, "Tourism, Competitiveness, and Societal Prosperity", Journal of Business Research, 44, 1999, pp. 137 - 152.

Ingemar DIERICKX et Karel CoOL, "Asset Stock Accumulation and Sustainability of Competitive Advantage", Management Science, 35 (12), 1989, pp. 1504-1511.

Giovanni Dosı, David J. TeECE et Sidney G. Winter, “'Les frontières des entreprises", Revue d'économie industrielle, 5I, 1990, pp. 239-254.

Jean-Luc DuBOIs et François-Régis MAHIEU, "La dimension sociale du développement durable : réduction de la pauvreté ou durabilité sociale ?", dans Jean-Yves MARTIN (dir), Développement durable? Doctrines, pratiques, évaluations, éd. IRD, 2002, pp. 73-94. Kathie M. EISENHARDT et Melissa E. GraEBNER, "Theory Building from Cases: Opportunities and Challenges", Academy of Management Journal, 50 (I), 2007, pp. 25-32.

European Commission-Commission européenne, Pour un tourisme côtier de qualité. La gestion intégrée de la qualité des destinations touristiques côtières, 2000.

Arvid FlagestAD et Christine A. HOPE, "Strategic success in winter sports destinations: a sustainable value creation perspective", Tourism Management, 22, 200 I, pp. 445-46I.

Minna HALME, "Learning for Sustainable Development in Tourism Networks", Business Strategy and the Environment, 10 (2), 2001, pp. 100-। 14.

Geert Hofstede, Culture's Consequences, Sage Publications, 200 I (3rd ed.).

LEADER, Évaluer le potentiel touristique d'un territoire. Guide méthodologique, 1997

[http://ec.europa.eu/agriculture/rur/leader2/rural-fr/biblio, consulté le 16 février 2010].

LEADER, La Compétitivité territoriale. Construire une stratégie de développement territorial à la lumière de l'expérience LEADER, Innovation en milieu rural, cahier $n^{\circ}$ 6/I, décembre 1999 [http://ec.europa.eu/agriculture/rur/leader2/rural-fr/biblio, consulté le 16 février 2010]. 
Matthew B. Miles et A-Michael Huberman, Analyse des données qualitatives, $2^{e}$ édition, De Boeck, 2003.

Edith T. PEnROSE, The Theory of the Growth of the Firm, Basil

Blackwell, 1959.

Jacques Perret, Jean-Paul Teyssandier et Ana Baldié, Le

Tourisme durable par l'expérience : le terrain commande, Odit

France, 2006.

Jacques Perret, Jean-Paul Teyssandier et Catherine Marette,

Piloter le tourisme durable dans les territoires et les entreprises, coll.

Guide de savoir-faire, Afit, 200 I.

Michael E. PORTER, Competitive Strategy: Techniques for Analyzing Industries and Competitors, Free Press, 1980.

Michael E. PORTER, "L'Avantage concurrentiel des nations"

(1990), dans Michael E. PORTER, La Concurrence selon Porter, éd.

Village Mondial, 1999, pp. 163-204.

Karen RajaOna DaKa et Jean-Luc DuBoIs, "L'intérêt de

l'approche par les capabilities pour le développement

socialement durable", Qualitique, 202, 2008, pp. 23-26.

Rimini International Conference on Sustainable Tourism,

Proceedings, 200I.

John RaWLs, Théorie de la justice, Seuil, 1987.

JR Brent RITCHIE et Geoffrey I. CROUCH, "The Competitive

Destination: A Sustainability Perspective", Tourism Management,

21: I, 2000 .

JR Brent RITCHIE et Geoffrey I. Crouch, The Competitive

Destination: A Sustainable Tourism Perspective, Cabi Publishing,

2003.

Ignacy SACHs, Stratégies de l'écodéveloppement, coll. Économie et humanisme, Les Éditions ouvrières, 1980.

Ignacy SACHs, L'Écodéveloppement. Stratégies pour le XXFe siècle,

Syros, 1997.

Amartya Sen, On Ethics and Economics, Backwell Publishers,

1991.

Jean-Paul TEYSSANDIER et Claudine ZYSBERG, "Pour un pilotage du tourisme durable. Éléments de méthode", dans Tourisme durable, coll. Cahier Espaces, n 67, éd. Espaces, 2000, pp. 204-208.

UNESCO, World Heritage List, Portovenere, Cinque Terre, and the Islands, 1997 [http://whc.unesco.org/en/list/826].

Corinne VAN DER Yeught, "Associer la population locale au développement durable d'une destination touristique : le programme Qualité de la vie du Parc national des Cinq Terres (Italie)", Qualitique, 202, 2008, pp. 4I-48.

World Commission on Environment and Development

(WCED), Our Common Future. Notre avenir à tous (1989), (2nd éd.), Éd. du Fleuve, 1987.

World Tourism Organization (WTO-OMT), Tourisme, horizon 2020. Résumé, 1999.
World Tourism Organization (WTO-OMT), Sustainable Development of Tourism, A Compilation of Good Practices, 2000. World Tourism Organization (WTO-OMT), Indicators of Sustainable Development for Tourism Destinations, 2004. Robert YIN, Case study research: design and methods, Sage Publications, 2003. 